effect of sunlight $77 \%$ of their patients with cancer had skin cancer, but with an unusual distribution for Australia with squamous-cell carcinoma accounting for three-quarters of the cancers and basal-cell carcinoma for the rest. In the general population this ratio is reversed. Furthermore, the squamouscell tumours in the transplant recipients were unusually aggressive.

The type of underlying renal disease may may be important. An increased incidence of transitional-cell neoplasms of the renal pelvis has been reported in patients with analgesic nephropathy, ${ }^{16}$ and patients with polycystic kidneys may have a higher. risk of kidney tumours. ${ }^{17}$ In some cases renal disease may be induced by extrarenal neoplasms; an association is well established between a nephrotic syndrome (usually due to membranous glomerulonephritis or a minimal-change type of nephropathy) and a variety of neoplasms. ${ }^{18}$

What about treatment? Epithelial tumours of the skin, the lip, and the uterine cervix may be treated by conventional surgical or radiotherapeutic methods, and no reduction in immunosuppressive treatment is usually recommended. The prognosis for those with carcinoma of the abdominal and thoracic organs and with most mesenchymal tumours is poor, however, and drastic reduction or discontinuance of immunosuppressive treatment is usually thought necessary with an inevitable increase in the incidence of graft rejection. ${ }^{115}$ Fortunately the overall incidence of neoplasia is still too low to be considered a contraindication to long-term dialysis and renal transplantation.

J R CurTis

Consultant Nephrologist and Senior Lecturer in Medicine,

Charing Cross Hospital,

London W6 8RF

1 Penn I, Starzl TE. Malignant tumors arising de novo in immunosuppressed organ transplant recipients. Transplantation 1972;14:407-17.

${ }^{2}$ Hoover R, Fraumeni JF. Risk of cancer in renal transplant recipients. Lancet 1973 ;ii:55-7.

${ }^{3}$ Matas AJ, Simmons RL, Kjellstrand CM, Buselmeier TJ, Najarian JS. Increased incidence of malignancy during chronic renal failure. Lancet $1975 ; \mathrm{i}: 883-6$.

${ }^{4}$ Miach PJ, Dawborn JK, Xipell J. Neoplasia in patients with chronic renal failure on long-term dialysis. Clin Nephrol 1976;5:101-4.

5 Sutherland GA, Glass J, Gabriel R. Increased incidence of malignancy in chronic renal failure. Nephron $1977 ; 18: 182-4$.

${ }^{6}$ Kinlen LJ, Eastwood JB, Kerr DNS, et al. Cancer in patients receiving dialysis. $B r$ Med $\mathcal{F} 1980 ; 280: 1401-3$.

7 Bryan FA. Seventh annual report of the National Dialysis Registry. 1975. (Research Triangle Institute Report No AK-7-7-1383.)

${ }^{8}$ Gurland HJ, Brunner FP, Dehn H, Harlen H, Parsons FM, Scharer K. Combined report on regular dialysis and transplantation in Europe, III, 1972. Proc Eur Dial Transplant Assoc 1973;10:XVII-LVII.

${ }^{9}$ Lindner A, Farewell VT, Sherrard DJ. High incidence of neoplasia in uremic patients receiving long-term dialysis. Cancer and long-term dialysis. Nephron 1981 ;27:292-6.

10 Wilson WEC, Kirkpatrick CH, Talmage DW. Suppression of immunologic responsiveness in uremia. Ann Intern Med 1965;62:1-14.

11 Newberry WM, Sanford JP. Defective cellular immunity in renal failure: depression of reactivity of lymphocytes to phytohemagglutinin by renal failure serum. $\mathcal{f}$ Clin Invest $1971 ; 50: 1262-71$.

12 Schwartz RS, Beldotti L. Malignant lymphomas following allogenic disease: transition from an immunological to a neoplastic disorder. Science 1965;149:1511-4.

13 Walford RL. Increased incidence of lymphoma after injections of mice with cells differing at weak histocompatibility loci. Science 1966;152:78-80.

${ }^{14}$ Mirra SS, Check IJ, Porter JD, Cox GW, Miles ML, Weidenheim KM. Rapid evolution of central nervous system lymphoma in renal transplant recipient. Lancet 1981 ;ii :868-9.

15 Sheil AGR, May J, Mahoney JF, et al. Incidence of cancer in renal transplant recipients. Proc Eur Dial Transplant Assoc 1980;17:502-6.

${ }^{16}$ Bengtsson U, Angervall L, Ekman H, Lehmann L. Transitional cell tumors in the renal pelvis in analgesic abusers. Scand $\mathcal{F}$ Urol Nephrol 1968;2: 145-50.

17 Roberts PF. Bilateral renal carcinoma associated with polycystic kidneys. Br Med f 1973;iii:273-4.

18 Friedman EA, Adler AJ. Renal disease due to extrarenal malignancy. In: Hamburger J, Crosnier J, Grunfeld JP, eds. Nephrology. New York: J Wiley and Sons, 1979.

\section{Sodium cromoglycate in proctitis and ulcerative colitis}

Most patients with symptomatic proctitis or distal ulcerative colitis respond rapidly to standard medical treatment including sulphasalazine and steroid-retention enemas. In some patients, particularly those intolerant of sulphasalazine, symptoms may be persistent, distressing, and difficult to relieve. Heatley and his colleagues argued that since exacerbations of ulcerative colitis may be mediated by a type 1 hypersensitivity reaction, which can be blocked in allergic asthma by sodium cromoglycate, the drug warranted evaluation in patients with ulcerative colitis. ${ }^{1} \mathrm{~A}$ small double-blind cross-over trial lasting six months in 12 patients with symptomatic ulcerative colitis suggested that treatment with sodium cromoglycate increased the patient's sense of wellbeing and was associated with improved sigmoidoscopic and rectal biopsy appearances. ${ }^{2}$

More recently a much larger controlled trial of sodium cromoglycate ( $800 \mathrm{mg}$ daily) failed to confirm these early findings; similar numbers of patients with symptomatic ulcerative colitis at the start of the trial improved, deteriorated, or maintained a steady state in both the treatment and placebo groups. ${ }^{3}$ The number of relapses among those patients who were in remission at the start of the trial was also similar in the treatment and placebo groups. In a separate study patients with ulcerative colitis in remission were allocated at random to receive either a low-dose or high-dose sodium cromoglycate regimen or sulphasalazine. The relapse rate was similar in the two groups receiving sodium cromoglycate, which proved considerably less effective than sulphasalazine in maintaining remission. ${ }^{4} 5$

The evidence from relapse rates in these trials ${ }^{45}$ suggests that sodium cromoglycate is little more effective than placebo treatment-but this view has now been challenged in a recent study where the relapse rate for patients taking sodium cromoglycate was $40 \%$ compared with $75 \%$ in the placebo group. ${ }^{6}$ There is, however, general agreement that the addition of sodium cromoglycate to conventional treatment confers no additional benefit. ${ }^{6}$ ?

The place of sodium cromoglycate in ulcerative colitis seems limited. It may be worth trying in symptomatic patients who cannot tolerate sulphasalazine, though even in this group of patients evidence for its value is conflicting. Desensitisation is probably a more effective and practical approach for patients with sulphasalazine intolerance ${ }^{8}$ - and an encouraging prospect is on the horizon with tests of a new agent comprising two molecules of 5-aminosalicylate, the active component of sulphasalazine, from which sulphapyridine (which is responsible for sulphasalazine intolerance) has been eliminated. ${ }^{9}$

Consultant Physician,

R N AllaN

General Hospital, Birmingham B4 6NH

${ }^{1}$ Heatley RV, Calcraft BJ, Rhodes J, Owen E, Evans BK. Disodium cromoglycate in the treatment of chronic proctitis. Gut 1975;16:559-63.

2 Mani V, Lloyd G, Green FHY, Fox H, Turnberg LA. Treatment of ulcerative colitis with oral disodium cromoglycate. A double-blind controlled trial. Lancet $1976 ; \mathrm{i}: 439-41$.

${ }^{3}$ Binder V, Elsborg L, Greibe J, et al. Disodium cromoglycate in the treatment of ulcerative colitis and Crohn's disease. Gut 1981 ;22:55-60.

- Dronfield MW, Langman MJS. Comparative trial of sulphasalazine and oral sodium cromoglycate in the maintenance of remission in ulcerative colitis. Gut 1978;19:1136-9.

5 Willoughby CP, Heyworth MF, Piris J, Truelove SC. Comparison of disodium cromoglycate and sulphasalazine as maintenance therapy for ulcerative colitis. Lancet 1979; i:119-22. 
${ }^{6}$ Whorwell PJ, Jones DC, Gent AE, et al. A double-blind controlled trial of the effect of sodium cromoglycate in preventing relapse in ulcerative colitis. Postgrad Med $71981 ; 57: 436-8$.

${ }^{7}$ Bucknell NA, Gould SR, Day DW, Lennard-Jones JE, Edwards AM. Controlled trial of sodium cromoglycate in chronic persistent ulcerative colitis. Gut 1978;19:1140-3.

${ }^{8}$ Holdsworth CD. Sulphasalazine desensitisation. Br Med f 1981;282:110.

9 Willoughby CP, Aronson JK, Agback H, Bodin NO, Andersson E, Truelove SC. Disposition in normal volunteers of sodium azodisalicylate, a potential therapeutic agent in inflammatory bowel disease. Gut $1981 ; 22: 431$.

\section{Blood pressures that fall on rechecking}

Many more family doctors are turning their attention to the national problem of the millions of mild hypertensives ${ }^{1}$ and starting case-detection programmes in their practices-a much more sensible setting than expensive special screening units. Once he has screened his patients, however, the general practitioner needs specific guidance on the interpretation of his findings, and this aspect has been given less attention by campaigners.

When a person is screened and his blood pressure is found to be high, the tendency is for the pressure to be lower when it is rechecked on a second occasion. This phenomenon of "regression towards the norm" is, in general, greatest in those patients with the highest pressures. Inevitably some people who were initially labelled hypertensive will then be considered to be normotensive-sometimes termed "labile" hypertension. ${ }^{2-4}$ There is, however, no theoretical or practical reason to believe that this spurious concept casts any light on the pathogenesis of hypertension. In fact, all blood pressures are labile and the higher the pressure the greater the lability. ${ }^{5}$

The phenomenon of regression to the norm has another side to it: those people whose blood pressures are low at first examination usually sustain a rise on rechecking. In a study in Renfrew, Scotland, ${ }^{6}$ the prevalence of hypertension and the average blood pressure of the community were unchanged when the whole population was re-examined one year later. Many people were no longer in the hypertensive category but they were replaced by others entering the category for the first time. When talking about labile hypertension many researchers consider only those people with pressures above an arbitrary dividing line which then settled; they omit those whose pressures rose on rescreening.

People with labile hypertension who have been investigated in detail have been found (not surprisingly) to be relatively free of damage to end-organs or left ventricular hypertrophy. ${ }^{2}$ Nor is it surprising that many "labile" hypertensives develop "fixed" hypertension with the passing of time. All blood pressures rise with advancing years, ${ }^{7}$ so that some patients will stop passing intermittently across the arbitrary dividing line between hypertension and normotension; their pressures remain as labile as ever but persistently above the line.

A second, quite distinct phenomenon which confounds the interpretation of follow-up studies is the orientation or defence reaction. ${ }^{8}$ Any patient will sustain a fall in blood pressure as he becomes more familiar with the frightening procedures to which he is exposed by his doctors. Substantial falls are found during placebo run-in phases of clinical trials. ${ }^{9}$ In the Medical Research Council trial of mild hypertension, ${ }^{10}$ for example, this was seen in patients having inactive treatment, though pressures tended to rise again after some months.

As all blood pressures are labile from minute to minute and from one clinic visit to another, what is the predictive value of casual blood pressure readings in comparison with lower readings taken later? Epidemiologists claim a predictive power from a single casual raised blood pressure reading. ${ }^{511}$ Nevertheless, Smirk et al ${ }^{12}$ reported that if patients were rested and basal blood pressures obtained life expectancy was more closely related to this basal value than to the casual pressure, and they found no relation with the difference between casual and basal pressures. In the Framingham study, conversely, the maximum blood pressure at screening was as useful an indicator of later risk as either the minimum or the average pressure. ${ }^{5}$ The amount of lability of pressure was not a predictor of outcome. Similarly Caldwell et al $^{13}$ found that near basal pressure measured in a manner similar to that of Smirk et al was no better correlated with damage to the end-organs than casual blood pressure. The testing of this point is extremely difficult-it is just not possible to admit large populations of patients to hospital merely for estimation of basal blood pressure. The results of current research do not, however, bear out the view of Smirk and his colleagues that the basal level of blood pressure is all important.

Nothing is known about the predictive value of continuous ambulant intra-arterial blood pressure recordings, which are usually lower than indirect cuff pressures. Many patients have intra-arterial pressures which are raised only when attending the clinic and remain persistently normotensive when going about their normal daily life. ${ }^{14}$ In view of the findings of the high predictive power of casual blood pressure readings in long-term follow-up studies, such patients probably still have a raised risk and can probably not be truly reassured. Even very high blood pressures can settle with rest or when the doctor leaves, ${ }^{13}$ but this does not imply that the patient concerned is immune to the complications of hypertension.

So what are the practical implications of blood pressure variability? Firstly, no clinician should make any therapeutic decision on the basis of a single blood pressure reading. If the average diastolic pressure after three clinic visits exceeds $100 \mathrm{mg} \mathrm{Hg}$ then in most patients antihypertensive drugs are worth while. ${ }^{10}$ Those whose blood pressure falls below but near this therapeutic dividing line deserve careful follow-up. And, since blood pressure generally rises with age, people whose diastolic pressures are below $80 \mathrm{~mm} \mathrm{Hg}$ need rechecking every three to five years. ${ }^{11}$

Senior Lecturer in Medicine,

D G BEEVERS

Dudley Road Hospital, Birmingham B18 7QH

1 Anonymous. Millions of mild hypertensives. Br Med f 1980;281:1024-5.

Stokes G, MacCarthy P, Frost G, Mennie B, Karplus T. Management of hypertension newly detected by health screening. Med f Aust 1981 ;i: 527-31.

${ }^{3}$ Carey RM, Ayers CR. Labile hypertension: precursor of sustained essential hypertension ? Am f Med 1976;61:811-4.

4 Frohlich ED, Kozul VJ, Tarazi RC, Dustan HP. Physiological comparison of labile and essential hypertension. Circ Res 1970;suppls 26, 27:55-63.

5 Kannell WB, Sorlie P, Gordon T. Labile hypertension : a faulty concept? The Framingham study. Circulation 1980;61:1183-7.

${ }^{6}$ Hawthorne VM, Greaves DA, Beevers DG. Blood pressure in a Scottish town. $\mathrm{Br} M e d \mathcal{F} 1974$;iii:600-3.

7 Anonymous. Why does blood-pressure rise with age ? Lancet 1981 ;ii: 289-90.

${ }^{8}$ Pickering G. Hypertension. Definitions, natural histories and consequences. Am F Med 1972;52:570-83.

${ }^{9}$ Dunne JF. Variation of blood-pressure in untreated hypertensive outpatients. Lancet $1969 ; \mathrm{i}: 391-2$.

${ }^{10}$ Medical Research Council Working Party on Mild to Moderate Hypertension. Randomised controlled trial of treatment for mild hypertension : design and pilot trial. Br Med $\mathcal{f} 1977 ; \mathrm{i}: 1437-40$.

11 Miall WE, Chinn S. Screening for hypertension: some epidemiological observations. Br Med f 1974 ;iii:595-600.

12 Smirk FH, Veal AMO, Alstad KS. Basal and supplemental blood pressures in relationship to life expectancy and hypertension symptomatology. $N Z$ Med f 1959;58:711-35. 